\title{
The impact of the Reformation on the formation of mentality and the moral landscape in the Nordic countries $^{1}$
}

VEIKKO ANTTONEN

University of Turku

\begin{abstract}
Along with the Lutheran world the Nordic countries celebrated the five hundredth anniversary of the Reformation on 31st October 2017. In this article I shall examine the impact of Luther's reform on the formation of mentality and the moral landscape in the Nordic countries. Special reference is made to the impact of Lutheranism on the indigenous Sámi culture, a topic which has been explored extensively by Håkan Rydving, the expert in Sámi language and religion.
\end{abstract}

Keywords: Reformation, Martin Luther, Nordic countries, national identity, mentality, Sámi, Laestadianism

The Protestant Reformation has played an extremely important role in the historical development of Europe during the last five hundred years. No other event in European history has received such widespread attention. It took place in the obscure fortress and university town of Wittenberg on 31st October 1517. A single hand-written text containing ninety-five theses against the beliefs and practices of the medieval Catholic Church opened a new era in European history. The well-known story tells us that the Augustinian monk and university professor Martin Luther came to his theological moment by the single act of nailing his ninety-five theses to the door of the Castle Church of Wittenberg (Roper 2016). Whether Luther used a nail to pin his theses on the door is a myth which cannot be verified. As Lyndal Roper writes in her biographical study of Martin Luther, the initial intention of the Reformer was not to spark a religious revolution, but to start an academic debate (Roper 2016, 2). Luther did not intend that the theses should be published or read more widely beyond a small circle of scholars

1 Acknowledgement: I thank the following people for their kind help and insightful discussions in writing this article: Kimmo Ketola, Henrietta Grönlund, Robert H. Nelson, Kirsi Salonen, Kurt Villads Jensen, and Jussi-Pekka Taavitsainen. 
(Roper 2016, 96).

The Reformation marks the break-up of Europe's religious unity. A common adherence to the Christian faith was a major component in the formation of European identity. The beginning of confessional plurality gave rise to the birth of a modern, literate, and intellectually rational Europe. One of the great thrusts of the Reformation, according to historians and sociologists of religion, has been the impetus towards universal education brought on by a theology which stressed the 'priesthood of all believers' (Hargrove 1971, 157-158). Individual conscience was detached from the institution of the church, which gave direct access to individuals to the sacred scriptures. In emphasising the importance of the individual the ethos of the Reformation paved the way for the emergence of humanism. In addition to the Enlightenment and the French Revolution the Protestant creation of the individual has often been related to the growth of science, education, economic development, and secularisation. Protestantism transformed the religious map of Europe by creating a new fabric of plural religious cultures in relation to the shifting boundaries between the religious and the secular domains of society. The outcome of the Reformation was several entangled religious Europes with differing dialectical relationships between nation states and the churches as well as other religious denominations and faith traditions. While Southern Europe remained Catholic, the three Northern Kingdoms in Scandinavia, Denmark, Norway, and Sweden, and to a certain extent also Estonia and Latvia in the Baltic, together with Germany and England, received Protestantism and have maintained their reformed religious heritage ever since. The total population of the reformed Nordic-Baltic nations is close to thirty million. The Evangelical Lutheran Churches in the Nordic countries are folk churches, or 'peoples' churches'. Insofar as the Nordic Evangelical Lutheran Churches are constituted by their members, the people, the outcome of the Reformation was in practice the formation of various state churches (Rémond 1999, 19-23).

In as much as Luther's Reformation created a new religious culture the aim of which was to question certain established beliefs and practices of Catholic faith revolving around the notion of grace and salvation, monastic vows, devotion to the saints, and the trade in relics, it was a matter of a more intense engagement with secular politics. During its five-hundred year history, in alliance with the state, the Lutheran Church has exercised more severe ecclesiastical control and discipline over the individual's autonomy in Nordic Lutheran societies than has been the case in Southern European Catholic countries. 


\section{The birth of state Lutheranism in Sweden-Finland}

Lutheran churches have become inextricably associated with nation-building in the Nordic countries by establishing the religious register, intertwined with definitions of citizenship, according to which people have become attached both to the church and the nation. However, the church did not acquire its hegemonic position over folk life in the Nordic societies through the Reformation. The church's influence on the collective social order had already been implanted during the Catholic era. Prior to the Reformation the church exerted total dominance over people's lives in medieval folk culture: their participation in the annual ecclesiastical feast days and lifecycle rituals as well as through its setting of moral standards according to which the common people attuned their behaviour and choices in the diverse situations of everyday life (see Talve 1997, 234). However, the Reformation was an extremely important event in the history of Nordic societies from the perspective of its impact on an individual's mentality and moral landscape. A change in religion is never, however, a linear process, but is 'driven by conflict, tension, and antagonisms between opposing forces' (Goldstein 2009, 158). After King Gustav Vasa (1521/23-1560) launched the Reformation in Sweden-Finland it became a more political than religious process. The Reformation played a key role in the making of the Nordic secular, state-church loyal and obedient citizen. In 2018 between sixty-five and eighty percent of all Nordic citizens belong to national Lutheran churches in all Nordic societies.

By the end of the sixteenth century (formally, 1593) Lutheranism had been integrated into the governing of the state and received a hegemonic status in the kingdom (see Markkola 2015, 4). After the Reformation King Gustav Vasa confiscated the land that had belonged to the Catholic Church and monasteries. He also decided on all clerical appointments and limited the rights of bishops and diocesan chapters (Hiljanen 2017, 195). The Reformation gave the king the opportunity to radically cut funding not only for the bishops but also for other ecclesiastical authorities for the benefit of the crown as well as for his own and the nobility's interests. In its earliest stage the Reformation in Sweden was more a political than a religious process. The loss of property and income entailed great distress for the church, which had earlier played an important role in the care of the poor and sick as well as in supporting talented young men in pursuing higher education. After the confiscations the church was no longer able to take care of these functions as it had previously. With the closing of the monasteries in Sweden, including the Diocese of Turku, which covered the territory of the present 
state of Finland, the Reformation meant an end to the monastic schools. The Reformation and the church's diminished income also complicated the activity of the local ecclesiastical schools, because parishes' income declined radically (Salonen 2018, forthcoming).

The transition from Catholicism to Protestantism had a profound effect on education, literacy, and reading skills in the Nordic setting. The Lutheran emphasis on the vernacular also evoked responses in Finland. The vernacular was elevated to the status of a language for religion and school education. In the Middle Ages three written languages were in use in the Eastland of Sweden, later to become Finland: Latin for ecclesiastical matters, Swedish for legal and administrative purposes, and the lingua franca of the Hanseatic League, Middle-Low German, for commercial correspondence. Finnish was not used in written form - or at least no evidence has survived of this apart from single Finnish words, such as place or person names, in documents written in other languages (Salonen 2018, forthcoming).

\section{The Nordic alliance between the Lutheran ethic and social democracy}

Robert H. Nelson, the American Professor of Political Economy and an observer of history, culture, and society in the Nordic countries, has argued that there is a historical continuity between a Lutheran ethic and social democracy in the making of the Nordic welfare state. In his book 'Lutheranism and the Nordic Spirit of Social Democracy' (2017) he makes two principal arguments: 1) the majority of the population in the Nordic countries remain Lutheran at their core in contemporary modernity; and 2) social democracy is a secular form of Lutheranism. Despite the challenges posed by Pietist and other new revivalist religious movements and worldwide trends in secularisation, Nelson maintains that the Lutheran ethic has never disappeared. Nelson argues against Max Weber's thesis in 'The Protestant Ethic and the Spirit of Capitalism' that no all-encompassing Protestant ethic exists. The Lutheran ethic does not resonate with capitalism as Calvinism does. Nelson argues that there is a scholarly neglect of the Lutheran ethic in assessing the importance of the Reformation for the shaping and development of the twentieth-century Nordic welfare state into 'a secular salvation of society' (Nelson 2017, 41). A Lutheran ethic provided a powerful normative foundation that underlay the political and economic rise of Nordic social democracy during the twentieth century. The Lutheran ethic was transformed and appropriated by the Nordic welfare states and found its expression in social democracy (Nelson 2017, 12, 37-52). 
The conclusions Nelson draws in his reading of the political, economic, and religious history of the Nordic countries are bold, but whether they are historically and methodologically valid is another matter. The ethical values listed in the Finnish Gallup Ecclesiastica 2015 poll as Lutheran - the importance of serving other people, sharing social responsibility, commitment to work and education (see Ketola et al. 2017) - can be read from the political programmes covering the entire political landscape, from left to right. What distinguishes them is the absence of references to God and the meaning of hymns and songs. Methodologically, Nelson's argument is based on the notion of implicit religion (Nelson 2017, 269). Without being explicit concerning the theory of religion Nelson's idea is that any organised activity in a society which implicitly provides a path to salvation in the sense of progress and deliverance from evil and death (as obstacles to life and progress) suffices for a definition of religion, even if the community of practitioners does not constitute a church in the Durkheimian sense. Nelson avers that Marxism, socialism, capitalism, and (Keynesian) economics are religions. Thus, what has taken place in the Nordic countries is a transition from the Lutheran God to the economic God for the benefit of the people, society, and the welfare state (see Nelson 2017, 198, 268-284).

\section{The Lutheran impact on the Nordic moral landscape}

What is the value of viewing the impact of the Lutheran religious heritage on the formation of internal political culture in the Nordic countries as religion? Does Nelson's 'economic theology' resonate, for example, in Sweden? In 2006 two Swedish professors of history, Henrik Berggren and Lars Trägårdh, published Är svensken människa? Gemenskap orch oberoende i det moderna Sverige (Is the Swede Human? Radical Individualism in the State of Social Solidarity). The authors depart from the view that it is a major error to think that Swedish political culture is unconnected with religious beliefs. In the second edition (2017) they added a new chapter, En luthersk modernitet (Lutheran Modernity), to correct their neglect in the 2006 edition. Berggren and Trägårdh show through historical records that, as in Finland, the working class was hostile to Christianity in early twentieth-century Sweden. In the 1919 syllabus reform of the Swedish public school the Social Democrats replaced Christian text books with Värner Rydén's Citizenship Knowledge (Medborgarkunskap, 1923) as compulsory reading (Berggren \& Trägårdh 2017, 383). Berggren and Trägårdh describe how the class-struggle approach to relations between the state and the Swedish church was superseded in the early 1930s, when there 
was again a Social Democrat prime minister. Whereas the former paradigm had been to abolish the state church, it was now planned to create a new alliance between the Lutheran Ungkyrkorörelsen (Young Church Movement) and the Social Democrats under the political construct of the folkhemmet, the people's home. This took place long before the notion was incorporated into the Swedish political landscape by the Social Democratic prime ministers Per Albin Hansson and Tage Erlander between 1932 and 1969 (Berggren \& Trägårdh 2017, 208-211, 385). The notion of the folkhemmet was modelled on the concept of the folkkyrka, the folk church, a notion common to all Nordic Lutheran churches, which expresses the transition from the state church to the folk church. The shaping of the folkhemmet was a radical effort to reform the Swedish church to make it more attractive to the working class as a social institution. Nathan Söderblom, Professor of the History of Religions and later the Archbishop of the Church of Sweden (Svenska kyrkan), was one of the early representatives of the Young Church Movement. Söderblom was an ecumenically minded patriot, whose mission was to steer the ideological content of the movement away from Swedish religious nationalism (ett Gods folk) to a universal understanding of Christianity's mission in the world (Berggren \& Trägårdh 2017, 384f.).

Berggren and Trägårdh's main postulation is that there is a social contract in Sweden that differs dramatically from those of other modern western democracies. Sweden is exceptional in its stress on the importance of the individual which, however, does not mean individualism in the sense of egoism and selfishness, but 'state individualism', an individual's autonomy in a relationship of dependency with the state. There is an intimate alliance between an individual and the state. The Swedes rely on the welfare state to liberate themselves from dependency on their kin and their own nuclear family. They prioritise their independence from family ties and traditional sources of prestige, because it is the state that provides the basic feeling of security. Sweden differs dramatically in its value profile compared to Germany and the United States. According to the World Values Survey the Swedes top the European table in their acceptance of divorce. Swedes are flexible and feel safe in making changes in their lives: they educate themselves, change their workplace, move, get divorced, and have children without becoming dependent on family, employer, or friends, knowing that there is a fine-tuned social security network to keep them safe (Berggren \& Trägårdh 2017, 84).

Although a degree of scepticism concerning national character literature is advisable, notwithstanding the anthropological and mentality-historical 
terminology on which it might be based, I shall refer to the comparative ethnological survey Svensk mentalitet (Swedish Mentality), conducted by the late Swedish Professor of Ethnology, Åke Daun (1989). According to Daun there is a goal in Sweden which causes people to strive for independence (självständighet, oberoende) even if solitude is the ultimate price to pay. The Swedes tend to avoid conflict and seek compromise. They try to hold back aggression in their social interaction. To the question 'Do you lose your temper easily if you don't get what you want' only 19 per cent of Swedish respondents replied 'yes'; in the case of Finnish respondents the figure was 31 per cent. The difference between men and women was even greater. Most Swedes consider lying bad behaviour, the figure being 60 per cent, compared with 13 per cent for the Danes, 22 per cent for the Finns, and 38 per cent for the Norwegians. Swedes regard pleasure as permissible, but 'mainly in forms of short breaks or ways of regaining strength needed for work'. Two major factors are taken to explain the Nordic mindset: climate and the Lutheran mindset. The climate factor concerns the impact of the temperature on people's mood with the shifts between winter and summer, warmth and cold, the bright and dark seasons, sunshine, wind, and rain. Lutheranism is taken to explain the Nordic puritan, obligation-centred worldview and inwardness and inaccessibility as the characteristic personality traits of the population. Lutheran puritanism is given as the main reason for people's feelings of sin and guilt. Too much pleasure gives rise to feelings of guilt. In quantitative surveys Lutheranism is used to explain the high correlation between the Lutheran ethic and an emphasis on hard work, efficiency, and the sense of order (Daun 1987, 56-210).

Nordic immigrants in the United States and Australia, for example, express their national identity both in native/indigenous and Lutheran terms. Wherever the Finns have migrated and settled they have built two things to distinguish themselves from the rest of the local population with their rites of passage: the sauna and the Lutheran church. The American anthropologist Ronald Bordessa has argued that Lutheranism in Finland is a dominant social reality. In Finland the forest is the iconic representation of the Lutheran individual. The iconic self in Finnish Lutheranism finds its expression in designated environments which preserve woodland and rock outcrops, allowing uninhabited nature to articulate God's will directly to each soul, without mediation by the ecclesiastical authorities. Bordessa argues that by turning inward to themselves and their environment the Finns have cultivated a strong sense of national affinity (Bordessa 1991, 90). 


\section{The spread of the Reformation to mythical Lapland}

The impact of the Reformation on the Sámi population was especially dramatic. ${ }^{2}$ Social-historical and ethnographic sources do not paint a very attractive picture of the Lutheran clergy sent by the kings of DenmarkNorway and Sweden-Finland to give pastoral guidance to the Sámi and the common people in the sub-Arctic and Arctic parishes of FennoScandia. Along with the Sámi population there had been fixed Finnish settlements in the Torne River Valley, for example, since the fourteenth century, when the Swedish crown had striven to establish permanent settlements (Lähteenmäki 2006, 63). Under the Danish-Norwegian and Swedish-Finnish kingdoms the Sámi and pioneer settlers were colonised by taxation obligations, law, and religion. Systematic census information on the sub-Arctic and Arctic inhabitants can be obtained from taxation records dating to the middle of the sixteenth century. The state's primary concern was to open access to the Arctic Ocean and take control of the people, iron-ore resources, and trade in the vast northern territory (Rydving 1995, 18-19; Norlin 2017, 40). During the reign of King Charles XI judicial and ecclesiastical administration in Sweden was organised according to a definition of nationhood that grouped people who, despite ethnic diversity, shared the same language, law, and religion. The ideal citizen was a peasant who did not migrate, paid taxes, and generally conformed to social norms. Pioneer settlement was boosted by a 1741 decree which promised settlers freedom from personal taxation for ten years and from taxation on their farms for fifty years. To become a settler, however, one had to show proof of one's blameless reputation and a sufficient knowledge of Christianity (Lähteenmäki 2006, 66). The settlement policy of the eighteenth and nineteenth centuries was closely connected with Lutheran orthodoxy and the view of Lapland 'as a land of wild barbarians who practised witchcraft' (Lähteenmäki 2006, 67).

2 The Sámi (also spelt Saami or Sami) are an ethnic minority group indigenous to the Arctic and sub-Arctic region in the northern parts of Scandinavia, Finland, and in the Kola Peninsula in the Russian Federation. The Sámi are the only indigenous people in the European Union to have their own language, belonging to the Finno-Ugric language family, and culture based on hunting, fishing, and nomadic reindeer herding. The Sápmi settlement area is approximately 300,000 to 400,000 square kilometres. Today, the total population is calculated at between 75,000 and 100,000. The Swedish scholar of the Sámi language and religion, Håkan Rydving, specifies that 'about half of the Sami speak the indigenous language, which is divided into nine or ten main dialects spoken in as many cultural areas. Of these, South, Lule, North, Inari, Skolt and Kildin Sami have written forms, which were created during the 1970s and 1980s and are taught in school, while North Sami, which is used by 85 per cent of Sami speakers, functions as an unofficial standard language' (Rydving 2013, 393). 
In his study 'The End of Drum-Time' Håkan Rydving writes that the encounter between the indigenous Sámi religion and Christianity involved a series of confrontations: some missionaries thought that 'a good flogging is the most powerful means of conversion' (Rydving 1995, 54f.). It was believed that punishments would deter people from the customs which missionaries categorised as 'idolatry', 'superstition', and 'sorcery' (Rydving 1995, 54f.). Threats of violence and punishment were characteristic of the Lutheran conversions, although there was no uniform ecclesiastical attitude towards issues concerning indigenous Sámi beliefs and religious practices. The role of the Sámi shaman drum - interpreted as the Bible of the Devil - was central in the confrontation between indigenous Sámi religion and Lutheran Christianity. 'For the Sami, the drum represented their threatened culture, resistance against the Christian claim to exclusiveness, and a striving to preserve traditional values' (Rydving 2010, 40). According to the principles of the Reformation, which developed into pietism and Lutheran orthodoxy at the end of the seventeenth and eighteenth centuries, the task and privilege of the clergy was not to teach but to interrogate (Laine 2007, 138). However, the principal effect of the Reformation was the introduction of the vernacular in transmitting the Word of God (see Norlin 2017, 51ff). The Sámi had absorbed elements of Catholic faith into their indigenous religion and cosmology long before the Reformation. During the early Middle Ages individual Sámis were baptised in the course of establishing trade connections across the Arctic Sea (Kylli 2012, 36).

The notion of land is key to understanding the confrontation between reformed Christianity and the indigenous religious traditions of the Sámi. Lacking as it does clearly defined geographical borders, the land has been traditionally indivisible for the Sámi: they possess no clearly defined territorial identity. In Sámi culture there is an indigenous spatial logic by which they locate themselves in their domestic territory. Locations of siida settlement, routes and paths for hunting, fishing and reindeer herding, and topographically anomalous sites and places along seashores, in mountain regions and forests, which they deem sacred, inextricably belong to their mytho-geographic worldview (on cognitive foundations of territoriality see Anttonen 2000; Anttonen 2013a; 2013b). In their ritual landscape sieidi-objects and saivo sacrificial sites played an important role. Conspicuous stone formations, erratic boulders, disintegrated rocks or stones, or anthropomorphic stones on the banks of a river or lake functioned as altars on which reindeers, deer, and fish were sacrificed to the Sámi gods, believed to have their abode at these sites. Sámi shamans employed holes and openings in the ground, 
cracks between rocks, and caves to exit and then re-enter the Jabmeaimo, the invisible underworld of the ancestors (see Rydving 2013, 393).

There is a fundamental distinction between Christian and indigenous notions of land. The categories 'land', 'territory', 'earth', and 'soil' are experientially deep and salient in Christian religion insofar as they have been Christianised. Land becomes good and soil fertile when taken into the possession of a Christian community by a process of sacralisation. The linkage between land and community is metaphoric and metonymic. In the biblical theology of Judaism and Christianity deserts, wildernesses, or other uninhabited terrains are valued as primary fields of divine dominance once they have become sacred battlefields in the Christian conquest. In his article on the Christian penetration of the landscape the Danish medieval historian Kurt Villads Jensen explores Crusade narratives, depicting the cleansing of the land from pagan influences. Jensen writes that ' $(t) h e$ missionary landscape was developed into the vineyard of the Lord by means of a two-step process. First it was proclaimed to be a desert, void of people, filled with wild animals, and laid bare by invaders and evil spirits. As such, it was only suited for ascetic hermits. [...]. The next step in this process was to proclaim it a possibly fertile land, one that could flow milk and honey if only the right persons came and did the necessary job' (Jensen 2013, 229-230). The fundamental distinction between the indigenous and Christian notions of land stems from the otherworldly emphasis on true human existence. As Jensen posits, 'The home here on earth became a place of exile, while the true fatherland, the true patria, became Jerusalem. [...] [T] he sacralization of the landscape by turning it into a new Jerusalem meant that Christians became totally liberated from the landscape in which they actually lived' (Jensen 2013, 232).

The American anthropologist Richard Sosis has produced a comparison of differences in land sacralisation between world religions and indigenous religions at three levels: physical qualities, internalisation mechanisms and cultural conceptions. His results can be summarised as follows (Sosis 2011):

- Indigenous populations tend to maintain a connection to their lands via their ancestors, ancestors with whom they are in regular communication.

- Contemporary world religions also assert that their ancestors once roamed their territory, but they are generally not a source of direct worship; they are more likely to be a source of inspiration rather than veneration.

- World religions undoubtedly rely more on theological argument and justification for the sustained holiness of their land than indigenous populations. 
- The doctrinal mode of world religions is also more dependent on repetitive ritual than the imagistic mode of religion that characterizes indigenous populations. Reciting the name of a sacred land over 100 times a day, as observant Jews do, is unheard of in traditional populations.

-World religions symbolize their sacred lands to a much greater extent than indigenous religions do, presumably to rally diaspora populations that do not reside within the sacred territory.

- There is less orthodoxy in indigenous populations, which may make it easier to settle territorial disputes among traditional populations.

- These differences between indigenous and world religions suggest that sacralizing land in the modern context may have stronger mechanisms of internalization than in the past.

Despite the threats to the indigenous Sámi religious traditions, there was a rich array of symbols and rituals available for internalising the indigenous religious heritage, such as mythic narratives about great shamans (noaidi) as well as the already mentioned forms of symbolisation and ritualisation of land and landscape (see also Kylli 2012, 165). In addition to ethnographic evidence archaeological grave-finds provide valuable sources to support this assumption. The Norwegian archaeologist Asgeir Svestad writes that 'the surrounding environment or mythical sphere (including pre-Christian graves and sacred places) must [...] have had a constitutive impact on the Sámi conversion to Christianity, suspending the opposition between confession to Christianity on the one hand, and the relation to Sámi religion, burial customs, and sacred landscape on the other' (Svestad 2013, 131).

Despite differences in land sacralisation between world and indigenous religions, the Christianisation of mythical Lapland is an exception to the general rule. Where the organised Lutheran mission encountered severe obstacles due to social distance between the clergy and the common people the pietistic Laestadian movement of the mid-1800s brought the message home. The Finnish social historian Maria Lähteenmäki provides an excellent account of the social cleft between the educated class and the common people in Enontekiö in Finnish Lapland. The doctrine of the Lutheran Church had not been very profoundly assimilated by the common people (Lähteenmäki 2006, 135). Laurentius Levi Laestadius, the Swedish-Sámi born botanist and theologian, was able to transcend the social gap between the clergy and people. Because of his cultural heritage - his mother was Sámi - Laestadius rejected the doctrinal mode of pastoral guidance and adopted an imagistic mode in transmitting Christian content to his Sámi and Finnish-speaking 
listeners (for a theory on the doctrinal and imagistic modes of religiosity see Whitehouse 2004). As Lars Levi Laestadius had been brought up amidst the fauna and flora of Lapland as well as forms of its visual and cultural representation, he understood the deep meanings of landscape in the Sámi mentality. Lähteenmäki writes that 'noisy trances, the cries, the clapping and the leaps of the members of the congregation had a downright frightening effect on outsider observers, who were warned not to attend the meetings' $(2006,85)$. Laestadius justified his crude language - the imagistic mode of transmission - as a vehicle to achieve his goal to make people perceive their inner world (Lähteenmäki 2006, 86). Laestadius was described by outsiders as a rude, arrogant, boorish, boastful, and conceited person. Laestadius called those who were Christian by name, not by the Spirit, sober drunks, chaste whores, and honest thieves. While attention to hygiene rules and control of people's eating habits, table manners, sleeping arrangements, conceptions of cleanliness, and social intercourse were an integral part of the clergy's evangelising toolkit, the aim of Laestadius was not to scrub the Sámi and settler populations clean, except where the consumption of alcohol was concerned (Lähteenmäki 2006, 79-94, 134-54).

Laestadius preached in Finnish and Swedish, but although the language used by the church among the Sámi in Sweden had been Finnish until the nineteenth century, Laestadius also preached in Sámi (Lähteenmäki 2006 , 88). Laestadius exploited the common people's prejudice against the clergy and authorities. He disapproved of the clergy because local parishioners had never received 'any spiritual benefit from the priests in return for all their great sacrifices' (Lähteenmäki 2006, 135f.). Laestadius succeeded in bringing two distinct conceptual worlds together in his sermons. How distinct the worlds were is well illustrated by stories by Petrus Laestadius, brother of Lars Levi and the Rector of Piteå. One story goes like this: 'A young Sámi man consulted a clergyman and asked to be admitted to confirmation classes so that he could get married. He attended confirmation classes in the rectory and returned to his dwelling in the fells. His folk gathered round him to ask for news, as was the custom. The young man answered in all seriousness that he had heard bad news: Jesus Christ has died. He assured his folks that they could fully rely on the truth of his story because the minister himself had related the matter many times. The family were shocked and began to ponder who might now become Christ. After consideration, the father of the family suggested that the young man himself would be an admirable candidate, because he got so well with the minister. If the young man would not agree, there 
was a risk that they would send someone from Umeå to be Christ among them' (cited in Lähteenmäki 2006, 135). ${ }^{3}$

Laestadius was at home in the indigenous landscape of the Sámi: he did not need to search for a new Jerusalem outside his own and his listeners' natural habitat.

\section{Conclusion}

An exploration of the impact of the five-hundred year history of the Reformation on the Nordic countries can never give an adequate account of the decisive factors which have shaped the Nordic mindset. From the perspective of the History of Religions and Religious Studies it is important that we pose questions about the history, and assess the possible influences, of religion - however we define and approach this illusive notion. In our efforts to understand and explain religion it is important that we never take the notion at face value. What we construct as 'religion' is always contextdependent. In the scholarly field of Religious Studies we pay attention not only to sources and data, whether literary or oral, historical or ethnographic, tangible or intangible. We also need a theory of religion and methods based on which what we call 'religion' can be deduced from the raw materials at our disposal in reference to our research questions. As the Nordic nation states have changed over the past five centuries, so have Christianity and indigenous religions. What remains constant is the politics by which people act on the issues important for them for survival and identity. Where the Nordic churches are concerned Lutheranism is a historical construct, which means that its 'essence' always depends on how it is essentialised. As social institutions, the churches are never stable in their view of the past and the future. The present-day reconciliation work that the Church of Sweden is doing to apologise for its colonial treatment of the Sámi people

3 Another story, told by Petrus Laestadius, dealt with a certain Sámi woman, who was on her death bed. The local minister tried to comfort her by promising her eternal life and the joys of Heaven. The old woman was silent for a long time listening to the words of the clergyman. Then she suddenly interrupted him and asked whether one could get liquor in Heaven. The priest tried to get her to turn her mind away from worldly concerns, but the old crone just shook her head and asked whether there was fire in Heaven, and was it warm up there? The minister continued his attempt to get her to think of other things, but she flew into a rage and shouted: "What? No fire and liquor? She had frozen and suffered a lot on earth, she said, and she had had enough. If the minister could not definitely promise her that she would not need to feel cold in Heaven, then she would rather go to Hell: there, as she knew, it was warm enough (Lähteenmäki 2006, 134f.). 
(see Lindmark \& Sundström 2017), for example, reflects the historical presence of the church in its relationship with the state and Swedish citizens. The Sámi population is also working on its history and future. In the Sámi parliament's programme the issues of faith, values, knowledge, skills, and personal living in the Sami culture are inextricably connected with their spatial understanding of what constitutes Sámi identity, society, and history, both in their domestic landscape and in how their understanding intersects and resonates with other nationalities and ethnicities at the Nordic, European, and global levels.

$$
* * *
$$

VEIKKO ANTTONEN is Professor Emeritus of Comparative Religion, University of Turku and Vice-President of the International Association for the History of Religions (IAHR). E-mail: veiant@utu.fi

Bibliography

Anttonen, Veikko

2000 Sacred Sites as Markers of Difference. Exploring Cognitive Foundations of Territoriality. In: Lotte Tarkka (ed.), Dynamics of Tradition: Perspectives on Oral Poetry and Folk Belief. Essays in Honour of Anna-Leena Siikala on her $60^{\text {th }}$ Birthday 1st January 2003, 291-305. Studia Fennica Folkloristica 13. Helsinki: Finnish Literature Society.

2013a Landscapes as Sacroscapes: Why Does Topography Make a Difference? In: Sæbjørg Walaker Nordeide \& Stefan Brink (eds), Sacred Sites and Holy Places: Exploring the Sacralization of Landscape through Time and Space, 13-29. Studies in the Early Middle Ages 11. Turnhout: Brepols Publishers.

2013b Religion in Prehistoric Finland. In: Lisbeth Bredholt Christensen, Olav Hammer \& David A. Warburton (eds), The Handbook of Religions in Ancient Europe, 372-91. Durham: Acumen.

\section{Berggren, Henrik \& Lars Trägårdh}

2017 Är svensken människa? Gemenskap och oberoende I det moderna Sverige. Stockholm: Norstedts.

\section{Bordessa, Ronald}

1991 The Iconic Self: Luther, Culture, and Landscape in Finland. In: Jamie Scott \& Paul Simpson-Housley, Sacred Places and Profane Spaces: Essays in the Geographics of Judaism, Christianity, and Islam, 81-92. Westport, CT: Greenwood Press.

\section{Daun, Åke}

1989 Svensk mentalitet. Ett jämförande perspektiv. Simrishamn: Rabén \& Sjögren. 


\section{Goldstein, Warren S.}

2009 Secularization Patterns in the Old Paradigm. Sociology of Religion 2009, (2), 157-78.

\section{Hargrove, Barbara W.}

1971 Reformation of the Holy: A Sociology of Religion. Philadelphia: F.A. Davis Company.

\section{Hiljanen, Mikko}

2017 Servants of the Crown or Trustees of the People? Personal Agency Among the Local Clergy (1550-1610). - Petri Karonen \& Marko Hakanen (eds), Personal Agency at the Swedish Age of Greatness 15601720. Studia Fennica Historica 23, 194-216. Helsinki: Finnish Literature Society.

\section{Jensen, Kurt Villads}

2013 Crusading and Christian Penetration into the Landscape: The New Jerusalem in the Desert after c. 1100. In: Sæbjørg Walaker Nordeide \& Stefan Brink (eds), Sacred Sites and Holy Places: Exploring the Sacralization of Landscape through Time and Space, 215-236. Studies in the Early Middle Ages 11. Turnhout: Brepols Publishers.

\section{Ketola, Kimmo \& Maarit Hytönen \& Veli-Matti Salminen \& Jussi Sohl- berg \& Leena Sorsa}

2017 Luthersk delaktighet: Evangelisk-lutherska kyrkan i Finland 2012-2015: En undersökning om kyrkan och finländarna. (Kyrkans forskningscentrals publikationer, 126) Tammerfors: Kyrkans forskningscentral. <http:// sakasti.evl.fi/sakasti.nsf/0/4D9073DDB9C38745C22576F20030A70E/\$ FILE/Kirkon_nelivuotiskertomus_II_osa_Luthersk_delaktighet_verkkojulkaisu-1.pdf>

Kylli, Ritva

2012 Saamelaisten kaksi kääntymystä. Uskonnon muuttuminen Utsjoen ja Enontekiön lapinmailla 1602-1905. Historiallisia tutkimuksia 259. Helsinki: Suomalaisen Kirjallisuuden Seura.

\section{Laine, Esko M.}

2007 Luterilainen ortodoksia. - Pertti Haapala \& Raisa Maria Toivo (eds), Suomen historian kartasto, 138-9. Karttakeskus.

\section{Lindmark, Daniel \& Olle Sundström}

2017 Samerna och Svenska Kyrkan. Underlag för kyrklig försoningsarbete. Möklinta: Gidlunds förlag.

\section{Lähteenmäki, Maria}

2006 The Peoples of Lapland. Boundary Demarcations and Interaction in the North Calotte from 1808 to 1889. Annales Academiæ Scientiarum Fennicæ. Helsinki: Finnish Academy of Science and Letters. 


\section{Markkola, Pirjo}

2015 The Long History of Lutheranism in Scandinavia. From State Religion to the People's Church - Perichoresis 13 (2), 3-15. <https://www. degruyter.com/view/j/perc.2015.13.issue-2/perc-2015-0007/perc-20150007.xml>

\section{Nelson, Robert $\mathrm{H}$.}

2017 Lutheranism and the Nordic Spirit of Social Democracy: A Different Protestant Ethic. Aarhus: Aarhus University Press.

\section{Norlin, Björn}

2017a Kyrkan, missionen och skolan. - Daniel Lindmark \& Olle Sundström (eds), Samerna och svenska Kyrkan. Underlag för kyrklig försöningsarbete, 37-50. Möklinta: Gidlunds förlag.

2017b Kyrkan och samiska kulturella uttryck. - Daniel Lindmark \& Olle Sundström (eds), Samerna och svenska Kyrkan. Underlag för kyrklig försöningsarbete, 51-63. Möklinta: Gidlunds förlag.

\section{Rémond, René}

1999 Religion and Society in Modern Europe. Oxford: Blackwell Publishers.

\section{Roper, Lyndal}

2016 Martin Luther: Renegade and Prophet. London: Vintage.

\section{Rydving, Håkan}

1995 The End of Drum-Time: Religious Change among the Lule Saami, 1670s1740s. Historia Religionum 12. 2nd Edition. Uppsala: Acta Universitatis Upsaliensis.

2010 Tracing Sami Traditions. In Search of the Indigenous Religion among the Western Sami during the 17th and 18th Centuries. The Institute for Comparative Research in Human Culture. Oslo: Novus forlag.

2013 Sami Religion. - Lisbeth Bredholt Christensen, Olav Hammer \& David A. Warburton (eds), The Handbook of Religions in Ancient Europe, 392-407. Durham: Acumen.

\section{Salonen, Kirsi}

Forthcoming Reformation and the Medieval Roots of the Finnish Education. - Kaius Sinnemäki, Anneli Portman, Jouni Tilli, \& Robert H. Nelson (eds), On the Legacy of Protestant Lutheranism in Finland: Societal Perspectives (Studia Fennica Historica). Helsinki: Finnish Literature Society.

\section{Sosis, Richard}

2011 Why Sacred Lands Are Not Indivisible: The Cognitive Foundations of Sacralizing Land. Journal of Terrorism Research 2011, 2 (1), 17-44.

\section{Svestad, Asgeir}

2013 Sámi Burials and Sacred Landscape: Aspects of the Impact of Materiality on Sámi Religious Conceptions and Practices. - Sæbjørg Walaker Nordeide \& Stefan Brink (eds), Sacred Sites and Holy Places: Exploring 
the Sacralization of Landscape through Time and Space, 111-39. Studies in the Early Middle Ages 11. Turnhout: Brepols Publishers.

\section{Talve, Ilmar}

1997 Finnish Folk Culture. Studia Fennica Ethnologica 4. Helsinki: Finnish Literature Society.

Whitehouse, Harvey

2004 Modes of Religiosity: A Cognitive Theory of Religious Transmission. Walnut Creek: AltaMira Press. 
